Article

\title{
How and Why Does Intra-Metropolitan Workplace Location Affect Car Commuting?
}

\author{
Petter Næss ${ }^{1, *(\mathbb{D})}$, Anders Tønnesen ${ }^{2}$ and Fitwi Wolday ${ }^{1}$ \\ 1 Department of Urban and Regional Planning, Norwegian University of Life Sciences, P. O. Box 5003 NMBU, \\ N-1432 Ås, Norway; hamde.fitwi.wolday@nmbu.no \\ 2 Department of Mobility, Institute of Transport Economics, Gaustadalleen 21, N-0349 Oslo, Norway; \\ anders.tonnesen@toi.no \\ * Correspondence: petter.nass@nmbu.no
}

Received: 10 January 2019; Accepted: 21 February 2019; Published: 24 February 2019

\begin{abstract}
This paper illuminates important causal processes that can explain differences between central, semi-central and suburban workplaces in commuting distances and modes. Its empirical base is qualitative interview material on the considerations and conditions underlying commuting behavior among employees of workplaces differently located within Oslo metropolitan area. The interviewees do not necessarily choose local jobs but rather travel a bit farther if this is necessary to find a more relevant job, especially if they have specialized job qualifications. Likewise, employers do not restrict their recruitment to local applicants. Workplaces close to the city center have a large number of potential employees within a short distance from the workplace and are, therefore, more likely to recruit workers locally. The interviewees' rationales for travel mode choices, such as time-saving, flexibility, convenience and stress avoidance, encourage commuting by transit to central workplaces and by car to peripheral workplaces. For example, transit is often faster and more convenient than car when commuting to central workplaces, while the opposite is often the case for commutes to peripheral workplaces. Rationales of avoidance of stress and frustration and of predictability and control work in similar ways.
\end{abstract}

Keywords: workplace location; commuting distance; commuting mode; transport rationales; qualitative research

\section{Introduction}

The aim of this article is to investigate the travel behavioral implications of the distribution of employment locations on a metropolitan spatial scale. Commuting behavior is an extensively researched topic within transportation and urban planning disciplines. The appeal partly comes from the fact that commuting to work is a subsistence/mandatory activity [1]. As a mandatory activity for most workforce participants, job commuting takes precedence over other activities and has higher tolerance threshold to longer trip distances/travel times. As such, commuting to work accounts for a larger average share of the daily travel time/distance budget. When job commutes are made by private car, the carbon footprint, congestion and urban air pollution associated with commuting becomes even more concerning.

However, compared to the ample number of studies investigating travel behavior impacts of residential location and neighborhood characteristics, the literature on impacts of workplace location on travel is of a much more modest magnitude. Indicative of this, the built environment variables investigated in two much cited meta-analyses of the impacts on travel behavior from the 'built environment' [2] and 'Compact development' [3] all use the residence as their point of reference. (For example, distance from the dwelling to $\mathrm{CBD}$, transit stop, etc., density of the residential neighborhood, 
degree of land use mix in the local area of the dwelling, or street network design in the residential neighborhood.) This also applies to the part of the literature on built environment effects on travel that focuses particularly on commuting.

The literature on whether it is centralization or decentralization of workplaces that reduces overall car commuting is still somewhat ambiguous (see below). Although centralized workplace locations are widely held to induce commuters to commit a larger share of their commuting by transit, a sizable number of studies, mainly from the US, still argue that decentralized employment locations reduce commuting distance, and thereby also vehicle miles traveled, by allowing people to choose local jobs.

The majority of studies of workplace location and commuting behavior have relied solely on statistical analyses, usually without much theoretical reflection. The underlying fundamentals of the models, i.e., the mechanisms of causal influences, are rarely discussed. However, in order to demonstrate that the location and local-area characteristics of workplaces within the metropolitan area cause differences in commuting behavior, it is important to show why the urban structural situation influences travel behavior. Qualitative research is then necessary $[4,5]$.

In line with Handy's [6] call for more of qualitative studies on the links between built environment characteristics and travel, this paper offers insight from qualitative interview research into the causal links between workplace location and commuting. The paper is based on the qualitative part of a mixed-methods study of the influence of workplace location on commuting distances and modes in the Oslo metropolitan area, Norway. Another, forthcoming paper [7] presents the quantitative part of the same study, where we conducted a questionnaire survey with 1346 respondents from workplaces differently located within the metropolitan area. The latter paper and the present one are meant as "companion papers", since it would exceed any reasonable length limit for this journal to combine both parts in one single paper. Analyzing 13 qualitative interviews, we explain causal mechanisms underlying important findings from the questionnaire survey included in the same research project. We thereby offer a more nuanced understanding of the causal relationships influencing travel behavior, which quantitative research can only illuminate to a limited extent.

The travel pattern we want to explain is the tendency of employees at suburban workplaces to commute on average longer distances and carry out higher proportions of their travel by car than their inner-city workplace counterparts, among whom transit and walking make up higher shares of the commutes. Among the respondents of the quantitative part of our study, the increase in distance of employment locations away from the city center leads to progressively greater share of commuting by car (Figure 1 to the left) while the proportion of regularly commuting by transit falls dramatically. At the same time, average commuting distances tend to increase, the farther away from the city center the workplace is located (Figure 1 to the right).
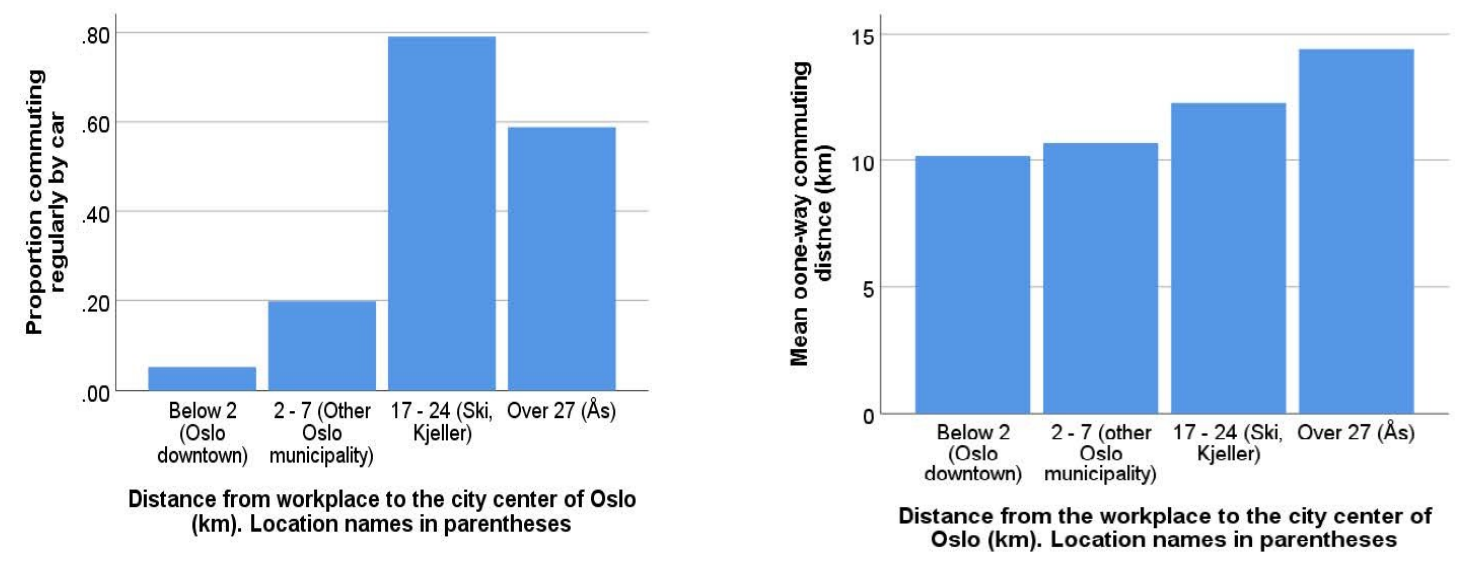

Figure 1. Proportions of employees commuting regularly for most of the commuting distance by car (to the left) and mean commuting distances (to the right) at workplaces located at different distances from the city center of Oslo. $\mathrm{N}=1346$. Source: [7]. 
Similar patterns for commuting modes have been found in numerous metropolitan areas around the world, including the San Francisco Bay area [8]; London and other large British cities [9]; the Dutch Randstadt area [10]; Atlanta and Boston [11]; Paris [12], and Lisbon [13]. The same applies to studies in Nordic cities, including Helsinki [14]; Copenhagen [15,16], Trondheim [17]; Stavanger [18,19] and Bergen [19] as well as some earlier studies in Oslo [18-20].

Some studies (particularly in the United States) have found employment deconcentration to reduce commuting distances [21,22]. However, other studies in USA and Europe conclude that job decentralization from inner to outer parts of cities and metropolitan areas does not contribute to reducing average commuting distances [8,11-13]. In a similar vein, earlier Nordic studies of office workplaces have found somewhat increasing commuting distances the more peripherally the jobs are located $[15,17]$.

Internationally, relatively few studies on land use and travel have included qualitative interviews [4,23-40]. Moreover, nearly all these studies focused on the influence of characteristics of the residential environment on travel behavior. To our knowledge, the present study is the first qualitative investigation of impacts of workplace location on travel modes and distances. In so doing, the paper will illuminate the mechanisms through which differences in employment location lead to differences in commuting distances and travel modes.

The rest of the paper is organized as follows: Section 2 presents the theoretical background for the interpretation of the data. Next, we describe the case city region in Section 3, followed by the research methods in Section 4. Section 5 presents the interviewees' rationales for choices of workplace location and their narratives about such choices. Commuting mode rationales and narratives are presented in Section 6. Section 7 discusses implications of the rationales for the influences of workplace location on commuting distances and modes. Lastly, Section 8 rounds the paper with concluding remarks.

\section{Theoretical Background}

A basic assumption of this study is that built environment characteristics have the capacity to exert causal influences on human actions such as travel [1,41-45]. These influences are not of a deterministic nature. The causal influences of built environment conditions are always only contributory, since a large number of other circumstances also influence individuals' decisions about whether, where, and how to travel. The ensuing transportation pattern is a result of people's resources, needs and wishes, modified by the constraints and opportunities given by the built environment as well as several other structural conditions of society. Philosophically, our study is inspired by the position known as critical realism [46-48]. Critical realism acknowledges human agents and social structures as well as the natural environment as capable initiators of mechanisms that might (or might not) result in empirical events, depending on the context-dependent combination of the multitude of causal mechanisms always at work except under closed experimental conditions [46].

The location of the workplace relative to the residential areas of its employees, combined with connecting transport infrastructure, determines how accessible a workplace is from the workers' homes. Accessibility is inversely proportional to the friction of distance [49], which depends on the time consumption, economic expenses and inconvenience involved when traveling from one place to another. Other things equal, accessibility will obviously be highest for the closest facilities. In addition, ease of access varies with travel mode, depending on circumstances such as the layout of the transit network, driving conditions along roads, conditions for walking and biking, and individual mobility capabilities.

In many urban regions, there is a higher concentration of residences in the inner than in the outer part of the region. This contributes to shorter average commuting distances among employees of inner-city workplaces. Workplaces are often located in an even more centralized pattern than is the case for residences [50]. For example, in a recent study of residential location and travel in Oslo metropolitan area [18], respondents' dwellings were on average located $14.4 \mathrm{~km}$ from the city center, compared to $9.7 \mathrm{~km}$ for their jobs. While office workplaces are often highly specialized (requiring high 
education within a particular discipline and maybe work experience within a quite narrow sub-field of professional practice), less specialized workplaces (e.g., within retail, primary education, kindergartens and health care) are more able to recruit employees locally [15-17]. Regarding travel modes, the city center can usually be reached by transit directly (without transfers) from all suburban transit corridors, since transit routes most often form a radial pattern centered on the downtown area. In contrast, accessibility by car is often at its lowest in the downtown area, where streets are often narrow, the number of crossings and traffic lights is high, and parking opportunities more scarce and expensive. As theorized by Allpass et al. [51], the city center is therefore the part of the urban region where transit accessibility is normally at its highest and car accessibility is at its lowest. Consequently, transit is much better able to compete with car travel for commutes to centrally located workplaces.

Individuals' transport rationales, i.e., the backgrounds, motivations, and justifications they draw on when they make transport-relevant decisions, make up important links in the mechanisms by which urban structures influence travel behavior [52]. Such rationales may be based on different rationalities $[53,54]$ and include instrumental, safety-based, comfort-based, esthetic as well as affective dimensions. In several qualitative studies of residential location and travel over the last couple of decades, 'choosing the best facility' and 'minimizing the friction of distance' have been identified as main rationales for location of activities, each featuring several sub-rationales [27-29,52]. Rationales for travel mode choice identified in these studies include, among others, time-saving, convenience, frustration aversion and a wish for physical exercise.

Another helpful approach to grasp such causal mechanisms is a time-geographical perspective, which is a framework for understanding human activity patterns related to travel and locations in space [1]. Workers' individual resources, motivations, and social environments influence their motivations for workplace locations (notably the balance between proximity and quality of the job) and their choices of travel modes. Combined with time-geographical constraints and the accessibility of various facilities, workers' transport rationales influence their choices of where to work as well as their travel modes for commuting.

\section{The Case City Region}

The Norwegian capital, Oslo, had 675,000 inhabitants in 2018 within the municipal border [55]. The continuous Oslo urban area, which includes 12 municipalities, had just above one million inhabitants in 2018 [56], whereas the functional urban region (here defined within a $50 \mathrm{~km}$ radius around the city center of Oslo) had around 1.45 million inhabitants. The population growth from 2017 to 2018 was 1.2 percent, following a 7 percent increase over the period 2013-2017. Despite this growth, land take has been low, illustrating a tendency of urban densification. Oslo's current population density (37 persons per hectare within the continuous urban area in 2018 [56]) is lower than in a major European city such as Berlin (54 persons per hectare in 2005), but considerably higher than in US cities such as San Francisco and Washington (19 and 13 persons per hectare, respectively) [57].

In total for all daily-life travel purposes in 2013/2014, car travel accounted for 53 percent, transit travel for 18 percent and non-motorized travel for 29 percent of the trips made by Oslo metropolitan area inhabitants. For commuting, the proportion of transit trips is higher (37 percent), non-motorized trips fewer and also a somewhat lower proportion of car trips than for non-work purposes [58]. Car drivers in Oslo have since 1990 been charged a fee for inward crossing of a toll ring around the inner suburbs. Two additional toll rings, one at the municipal border and one around the inner city, are planned to be implemented in 2019.

Like many western cities, Oslo has undergone a phase of deindustrialization. Today the Oslo region is Norway's most important administrative-, knowledge and finance center. The number of workplaces is by far largest in the municipality of Oslo, with the municipalities of Asker and Bærum having most of the workplaces located outside the core city area [59].

Figure 2 shows how job and population densities, respectively, vary between different parts of Oslo metropolitan area. 


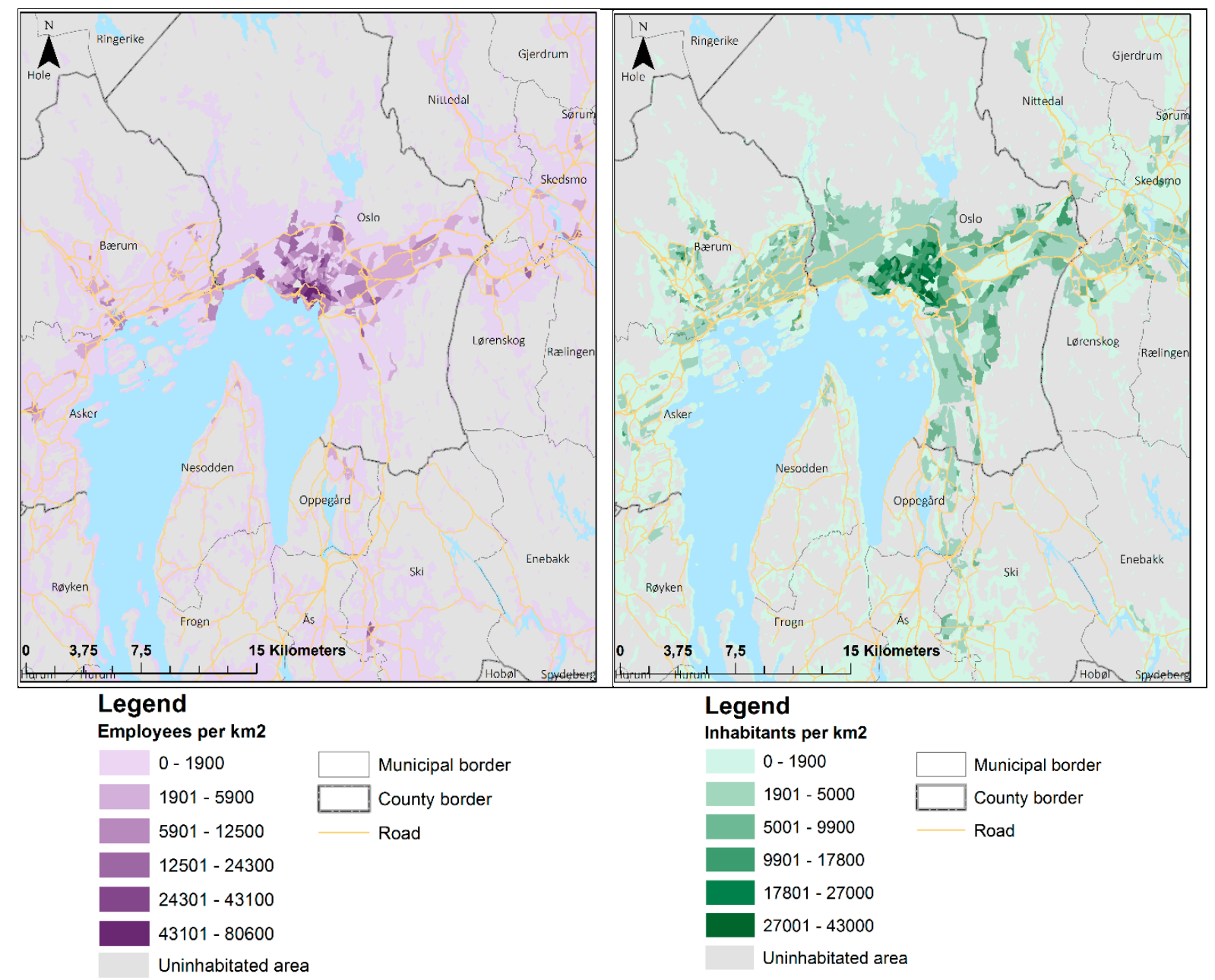

Figure 2. Job densities (to the left) and population densities (to the right) within different parts of Oslo metropolitan area. Maps by Anja Fleten Nielsen, Institute of Transport Economics.

\section{Methods}

The main empirical base of this paper is the qualitative part of a mixed-methods study. The quantitative part consisted of a questionnaire survey among employees of 14 workplaces located in different parts of Oslo metropolitan area (see Figure 1). We were only able to include workplaces where the directors were willing to aid in the process of questionnaire dissemination. Obtaining consent from companies to participate turned out to be more difficult than expected, especially within the municipality of Oslo. (We sent out invitation letters to all private companies and public-sector workplaces in the municipality of Oslo with more than 30 employees (nearly 500 altogether), but only got acceptance from four of them. One of these workplaces (Oslo Science Park) included several individual companies clustered at the same site. The willingness among Oslo employers to participate in the study was substantially reduced because Oslo companies and public-sector entities had been involved in several other questionnaire surveys on travel behavior during the year preceding our survey.) In the surrounding municipalities, employers were generally more willing to participate in the study, and we were thus able to include a satisfactory number of workplaces located at varying distance from the three second-order centers Ski, Lillestrøm and Ås. However, both in Oslo and in the neighboring municipalities, the participating workplaces turned out to be dominated by jobs requiring academic education. Only two workplaces with jobs predominantly requiring vocational education accepted to participate. 
The main qualitative part included 13 interviews with employees at eight of the investigated workplaces. We selected interviewees among the more than 450 questionnaire respondents who had volunteered for this task. The chosen respondents were those whose individual characteristic and/or answers to questionnaire questions were particularly relevant for the qualitative study. Selection of interviewees was based on four criteria. First, and most important, was to have a fair distribution of people working in different parts of the urban region. This selection was based on our knowledge of the different levels of accessibility by car, transit and non-motorized modes in different parts of urban regions (see also Section 2). Among the interviewees, five had workplaces in outskirt areas, two in semi-central areas and five in central areas. Second, we wanted to include some persons having changed job location (and in some cases residential location too) within recent years. This was done to include reflections and comparison between previous and current travel practices and choices. Third, in addition to including interviewees whose commuting patterns were typical of their workplace locations, we also sought to include some with atypical commuting patterns. Last, we wanted to have variation between the interviewees in terms of gender and age.

Reflecting the overrepresentation of 'knowledge industry' workplaces in the questionnaire survey, persons with high income and particularly with long academic education are overrepresented among the interviewees, compared to the populations in the city region. This is a limitation of the study, since the interviews may not provide sufficient information about the influence of education level and work profession on travel behavior. Most of the interviewees also work closer to their place of residence than the survey respondents do on average. Figure 3 shows the locations of the interviewees' workplaces. Appendix A shows key demographic and socioeconomic characteristics of the interviewees as well as their job types and locations.

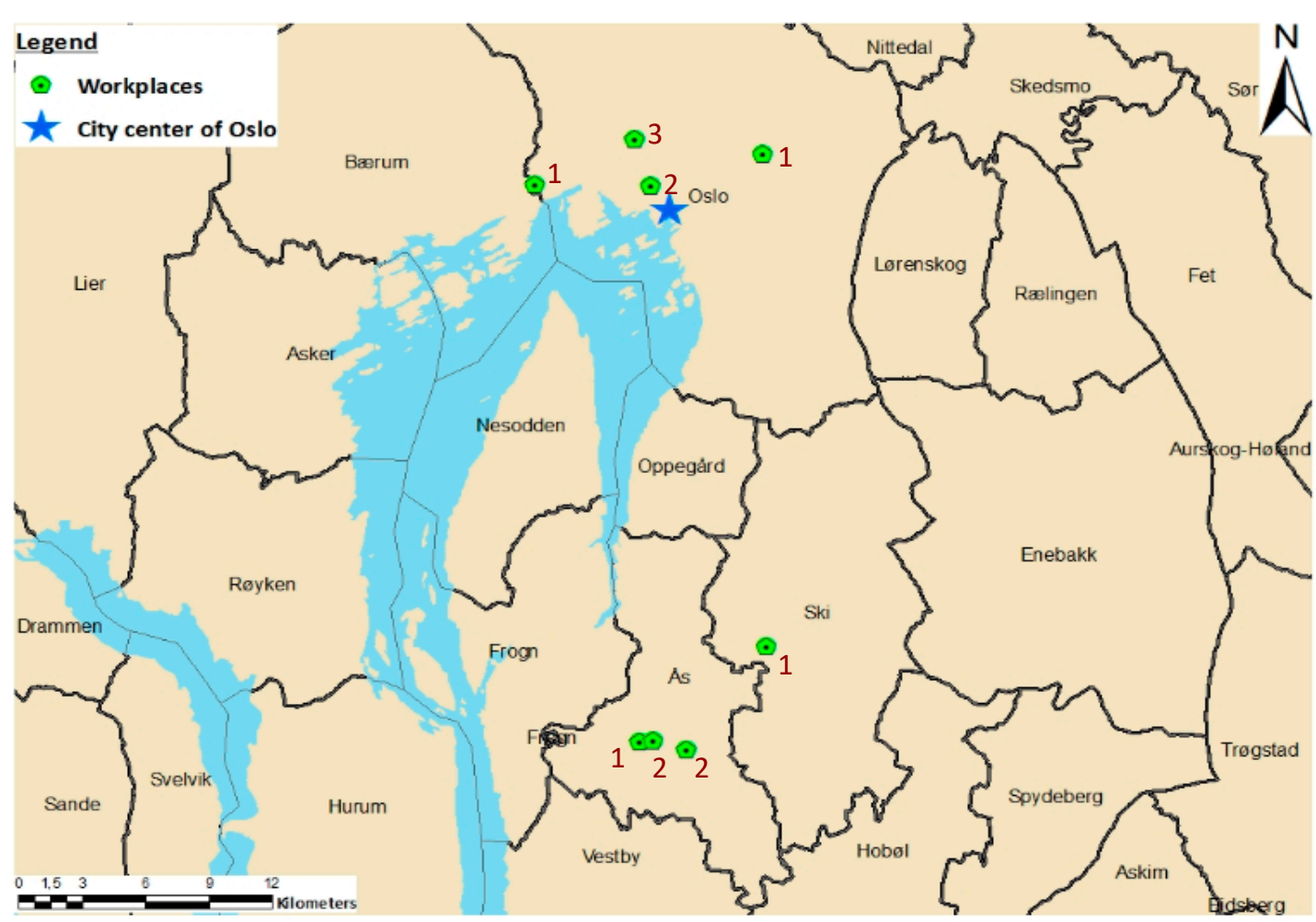

Figure 3. Location of interviewees' workplaces and number of interviewees at each location. The asterisk indicates the city center of Oslo.

As described above, the study seeks to provide a deeper understanding of causal relationships influencing travel behavior. By analyzing narratives and the transport rationales in the Oslo region, we aim for the findings to be relevant not only to this region alone, but also to others. This is in line with Gerring's [60] goal for case studies, where intensive studies of a single unit are conducted to 
shed light on broader classes of units. This raises the question of the possibilities of generalizing from case studies, and if so, what this would contain. Yin [61] suggests that case studies can provide analytic generalization. Here, the researcher generalizes findings to theory. In line with this approach, we have not sought representativeness in relation to selection of city case or interviewees. Instead, and based on our knowledge from the quantitative part of our study as well as other studies on different levels of accessibility by car, transit and non-motorized modes across the urban region, our main selection criterion was to have a reasonable distribution between the peripheral, semi-central and central workplaces within the Oslo urban region. We also considered it important to include persons who had changed their workplace location and/or place of residence recently. The narratives of these interviewees about reasons for relocating, and the subsequent impacts of their relocations on travel, provided important information of how the location and neighborhood characteristics of workplaces influences commuting. By selecting some interviewees who had changed their residential location to live closer to their suburban jobs, we also obtained information about the conditions that had to be in place for workers at suburban workplaces to commute by modes 'atypical' for their workplace locations. Together, the intention was for the qualitative interviews to provide more nuanced knowledge of the travel behavior and the influence of urban characteristics.

The interviews (usually lasting between 35 and 40 minutes) were semi-structured addressing several pre-identified topics. (The interviews were shorter than in our earlier qualitative studies on residential location and travel, where each interview typically lasted for 60-90 minutes and sometimes even longer. The shorter duration in the present study has to do with the narrower scope, centered on one particular travel purpose (commuting).) Each interview was conducted in an open manner, where the interviewees were first given the opportunity to speak freely for a few minutes about their thoughts regarding their choice of workplace and travel modes for commuting. The interview guide is shown in Appendix B.

The interviews were conducted in the spring of 2018, all at the interviewees' workplaces except one, which was conducted in the interviewee's home. Each interview was audio-recorded and fully transcribed. The main purpose of our qualitative interviewing was explanatory [40], aiming to deepen the understanding that quantitative research has already suggested. However, we also tried to be open for new, previously overlooked issues, thus including an explorative element. Our explanatory approach is different from mainstream qualitative interview research, where some literature advocates either entirely descriptive accounts (e.g., [62]), sees interviews as an exploratory method for discovering unexpected things, or considers interviews as 'bottom-up' way of generating research questions within loosely defined topics (e.g., [63]). Instead, our use of interviews is more inspired by scholars such as Cresswell [64] and Maxwell [65], who acknowledge the potential of interviews in explanatory research, and by a general critical realist quest for illuminating the underlying causes of observable patterns such as the correlations found in statistical analyses [46].

Distinct from methods such as "meaning categorization", "meaning condensation", [66] or the counting of how frequently specific words and concepts appear or are combined within a text, our analysis of the interview material was based on holistic interpretation of the narratives of the interviewees. An interpretation scheme, developed in our earlier studies (see, for example, [52] was used to structure the analysis of the interview material. Each interpretation was checked by one other research team member. Given the overall holistic approach, the interpretation scheme helped keeping our focus on the research questions and forced us to make efforts to try to understand what the information given by the interviewees meant to each of the research questions that we tried to address (yet with an open view to possible new and explorative elements). Appendix $C$ shows an excerpt of the final synthesizing for the question group "Rationales for travel mode choices".

In addition to the 13 interviews with employees, we also carried out brief interviews with management representatives at nine of the workplaces, focusing on, among others, the degree of job specialization and the size of the catchment area for staff recruitment of each company. 


\section{Workplace Location}

In this section, we first present rationales for choosing workplace locations identified from the qualitative interviews. The rationales were normally not stated explicitly by the interviewees. Instead, they were inferred from the interviewees' narratives about workplace locations, acceptable home-work distance if they were to find a new job, and statements about any changes in workplace, and so on. Therefore, in Section 5.2 we take a step back by describing interviewees' narratives and linking them to the presented rationales. In the last part of the Section (5.3), we briefly reiterate some of the information given by management representatives.

\subsection{Rationales for Choosing Workplace Location}

In line with what has been found in similar previous studies, two main rationales influence the interviewees' choices of workplace location: choosing the 'best facility' (mostly expressed in terms of job contents) and limiting the 'friction of distance' (mostly expressed in terms of travel time). These rationales correspond to findings in several qualitative studies of residential location and travel over the last couple of decades, cf. Section 2.

The term 'choice of workplace location' of course does not imply that we believe that individuals may freely decide to become employed at a particular workplace. They also need to be selected for the job by the employer (cf. Section 5.3). However, there is still scope for the individual job seeker to decide on the geographical range within which she or he is willing to apply for vacant jobs.

All 13 interviewees emphasize job content as the key criterion for the attractiveness of a job opportunity, and sometimes interviewees specify this to mean that the tasks of the job must match the interviewee's qualifications achieved through their professional education/earlier work experience (ID1, ID3, ID5 and ID9). IDs 2 and 10 mention good colleagues/work environment as an additional criterion. Only one interviewee (ID11) mentions salary level as a criterion, and as a rationale for workplace location choice, this seems less prominent among the interviewees than do features pertaining to the content of the job.

Nevertheless, salary is normally an element that plays a role in people's judgment about the attractiveness of different job opportunities. One reason why salary level is mentioned so rarely could be that most of the interviewees (unlike the one who actually mentions salary) are employed in the public sector where income levels do not vary much as long as the content of the job is similar. A satisfactory job content may also indirectly contribute to a good salary. Here, it should be noted that all interviewees except one have university or university college educations, most of them at master level.

For all interviewees, the wish for the most attractive job (the 'best facility' workplace) is in some way traded off against a wish to avoid too long and cumbersome commutes (i.e., to limit the 'friction of distance'). Often, the interviewees express this in terms of travel time, but other elements of the journeys to/from work may also be referred to as negative, notably the need to shift from one transit line to another. The rationale of limiting the friction of distance does not appear as a wish to minimize travel time but rather to keep it within some acceptable limits. Within these thresholds, which vary considerably between different interviewees, the content of the job appears to be more important than differences in travel time. Some interviewees want to travel to and from their workplace by non-motorized modes if possible, and for those interviewees the friction of distance refers to the actual physical (Euclidian) distance and the biking conditions along the route. None of the interviewees mentions the economic expenses of commuting as an element influencing their choice of workplace.

Interviewees who regularly bring and pick up children at kindergarten or school (ID2, ID3, ID8, ID12 and, to some extent, ID5), tend to place greater emphasis on limiting travel time than interviewees without such responsibilities.

For the remaining interviewees, the rationale of choosing the best job content is clearly more important than minimizing travel time, reflected in quite wide levels for acceptable commuting travel time. Nevertheless, most of them actually have moderate or short commuting distances (ID5, ID7 and ID13). For ID 7 and ID 13, this is facilitated by their relatively central residential locations, and for 
ID5 by her finding a suitable job in an eastern district in the same direction from the city center as her own residence.

For at least four of the interviewees (ID3, ID6, ID8 and ID13), the decisions about residential location and workplace location are closely related, based on considerations of the commuting distances of both spouses in households with two wage-earners. For these interviewees, the rationale of limiting the friction of distance thus applies to both workplace location and residential location and includes their own as well as their partners' commute. For example, given the specialized job qualifications of ID3 and ID8 and their preference for living in low-density, rural-like surroundings, getting jobs at a university campus in the peripheral part of the region and simultaneously moving to the nearby settlement appeared the best way of combining the various rationales.

Interviewees' emphasis on limiting travel time could superficially be interpreted as an indication of an 'economic man' perspective where individuals try to avoid wasting time that could alternatively be spent on income-generating activities. However, the reasons interviewees state for being concerned about travel time show that this is in some cases motivated by caretaking responsibilities (ID3, ID5, ID12) and otherwise mainly by a wish for more leisure time (and not, as sometimes assumed in transport project evaluation, by a wish to have more time available that could be put into additional paid work).

\subsection{Interviewees' Narratives Exemplifying Workplace Location Rationales}

Above, two main rationales were presented as central to choices of workplace location; choosing the best facility and limiting the friction of distance. The conducted interviews illustrate well how the two work in conjunction. This means that the wish for the most attractive job (the 'best facility' workplace) in some way is traded off against a wish to avoid too long and cumbersome commutes. For one interviewee (ID8), the job content of a university job at the outskirt was so attractive that she decided to move out of Oslo to reduce the commuting distance. This decision was encouraged by the fact that her partner was already working at this outskirt location:

[My partner] was completely in despair over his work travel and thought it was terrible to commute from Oslo every day. And I fancied the thought of taking a PhD. When the opportunity came, to move here, it was a complete match actually.

For another interviewee (ID10), commuting from the outskirts to the city center, a more satisfactory job content was a central reason for changing job. Still, workplace location played a role in terms of what jobs she actually applied for. Seeking teacher positions, she had the opportunity to work at a number of different workplace locations. However, in line with a rationale of limiting the friction of distance she ended up at a school located relatively nearby. Asked to identify factors involved in her choice of a new job, she stated:

It was the job content [being the main reason for her wanting to change job], but at the same time it was not that important that I would have switched to a school located anywhere ( . . ). [T]he commute was decisive for which schools I found interesting.

Looking closer at one informant living and working in the central city, she envisions also her next job to be located centrally (ID12). With loose talk of her job potentially being moved to a neighboring city Lillestrøm, it seems clear that she will not follow if this is implemented:

[I]f my job had been moved to Lillestrøm, I would have started to apply for new jobs. Because it would not have been practical for me in my daily life, with children, to commute to Lillestrøm. ( ... ). [A]nd I have not really had any desire of working at Lillestrøm. If so, I would sort of not have lived where I live.

The three interviewees illustrate how choice of workplace location results from the combined workings of the rationale of seeking the best facility and that of limiting the friction of distance. They 
illustrate different situations; one has moved closer to her new work, one was not willing to apply for a new job with a cumbersome commute and one is ready to shift job if her present one is moved out of Oslo. Still, the three interviewees share a desire of keeping travel time within some acceptable limits.

\subsection{Employers' Recruitment Policies}

Our interviews with managers at some of the workplaces show that most of the companies and institutions consider the entire Oslo metropolitan area as their recruitment catchment area, or at least the part of it (i.e., to the south, west or east of Oslo) where their workplace is located. For workplaces located in one of these peripheries, the catchment area in some cases expanded into a neighboring urban region (e.g., the region to the southeast of Oslo metropolitan area). University staff was, as expected, recruited from all over the metropolitan area and often from foreign countries. Some workplaces that we expected to be non-specialized turned out to include groups of staff that were quite specialized. For example, an upper secondary school offered electronics and industrial production as possible study profiles, which required highly specialized teaching staff. Administrators at nursing homes also told that it was difficult to recruit educated nurses and that they had to recruit from all over the southern part of the metropolitan area, and even from abroad.

\section{Commuting Travel Mode Choice}

In this section, we first present rationales for choosing travel modes for commuting identified from the qualitative interviews. As for Section 5 the rationales were typically not stated but instead inferred from the interviewees' narratives about, among others, travel behavior to present work or changes in travel behavior after moving to a new dwelling or changing to a different workplace location. Also in this section we take a step back in Section 6.2 by describing interviewees' narratives and linking them to the rationales presented in Section 6.1.

\subsection{Rationales for Travel Mode Choice}

The interviews show a number of different rationales influencing choices of travel modes for commuting. Some of them appear more important and widespread than other rationales, with time-saving standing out as the dominant one in most of the interviews. Other important rationales are limitation of travel expenses, convenience/easiness, flexibility and physical exercise. A number of other rationales are encountered in fewer interviews but may still be of high importance to the interviewees to whom they apply. This group of rationales include affective dislike, social contact/communication, caretaking, safety, stress avoidance, frustration avoidance, control and predictability, environmental concerns, and obligation.

Time-saving is the dominant rationale for travel mode choice for journeys to work for eight of the 13 interviewees (ID1, ID3, ID4, ID5, ID9, ID10, ID11 and ID12) and for one more interviewee (ID6), given that he and his family had for other reasons chosen not to have a car. In addition, time-saving is one of two main rationales that appear to be of equal importance to two interviewees (ID2 and ID8) and an important but not clearly dominant rationale for one interviewee (ID13). Only for one interviewee (ID7), time-saving does not appear as any important rationale for choosing commuting modes. This interviewee lives close to his workplace and has no mandatory tasks to carry out on his way to and from work, such as bringing or picking up children.

For most interviewees, the reasons why time-saving is important are not stated explicitly-the desirability of saving time seems to be taken for granted. Some interviewees are, however, specific about why time-saving is important to them. This applies to ID5 and ID11 (both female), who state that time-saving is important because they want to spend time together with the children instead of spending it on traveling. Distinct from this, one interviewee (ID6), working at a centrally located workplace, wanted the commute to be not too short, since his present moderate-length commute allowed him to 'clear his thoughts' on the way home. This interviewee still chose bike or transit as commuting modes instead of the slower mode of walking. 
The emphasis on time-saving as a rationale for travel mode choice appears to be stronger among those interviewees who need to travel a long distance between home and job than among those whose commuting distance is short. Time-saving is also emphasized by some interviewees who have relatively recently relocated their job or residence to reduce their commuting distance. For these interviewees, the emphasis on time-saving as a travel mode choice rationale refers more to the situation before the relocation, when they still had to commute a considerable distance, than to their present commuting.

Limiting travel expenses appears as an important rationale for some interviewees, influencing their travel mode either indirectly at a strategic level by affecting their car ownership (ID5, ID6 and ID12) or directly (ID1 and ID7).

ID5, who regularly travels to her workplace as a car passenger with her husband states that she would rather travel by transit than purchase another car enabling here to drive on her own to her job if she could not drive with her husband. ID6 and his family have decided not to own a car, based on a rationale of money-saving along with a predilection for a car-less lifestyle. ID12 emphasizes the high cost of car and plans to sell it, since she does not have much need for it given her and her husband's workplace locations and the location of their dwelling, all within central parts of the city.

In the interviews with ID1, ID7 and ID9, limitation of travel expenses appears as a rationale influencing travel mode choice directly and not via car ownership, and for ID12 too, travel expenses are one of the reasons for not driving to work while she still has the car. ID1 has a strong economic incentive for traveling by car, since he has a company car where the company pays for all his driving regardless of purpose and for which he has to pay tax. It seems, however, that ID1 would have commuted by car also in the absence of this economic rationale for choosing the car mode, both because of the considerable time-saving associated with driving instead of commuting by transit and because of his need to use the car during the workday (see below). ID7 is frustrated by the costs of car driving (including toll fees) but does on the other hand not seem much concerned about the costs of the monthly transit card.

Conveniencelease of travel is a rationale for travel mode choice encountered in several interviews (ID1, ID7, ID9, ID12 and ID13). This rationale is closely related to a rationale of flexibility (ID1, ID4, ID10 and ID13). For interviewees working in areas with high transit accessibility or at a short distance from the dwelling, travel modes other than car driving are the ones perceived as convenient and flexible. For example, ID4 commutes by transit partly because he finds it the most flexible mode (in addition to being the fastest). ID7 alternates between transit and walking as he considers these modes the most convenient ones. For ID12, the flexibility and easiness of biking when bringing her child to/from kindergarten and when making errands on her way home are important reasons for her modal choice. ID13 uses the word convenience to describe her switching from sporadic car usage to commuting nearly always by e-bike, which she finds much more practical and easy. For interviewees working at locations poorly accessible by transit, the rationales of convenience/easiness and flexibility induce them to deselect transit if this mode requires shifts between different routes, particularly if waiting times and/or walking distances are long. These interviewees typically characterize transit as inflexible. The mode of travel chosen instead is usually car if the commute is long (ID1 and ID9), but bike may be chosen if the distance is within what the interviewee considers is acceptable for this mode (ID10).

A wish to obtain physical exercise when commuting influences, at least to some extent, the travel mode choice of five interviewees (ID4, ID6, ID9, ID10 and ID11). This rationale is particularly strong for ID10, who is an active sports cyclist. For ID4, the physical exercise involved is the main reason why he sometimes uses a city-bike when traveling home from work. ID6 commutes by bike instead of transit during the summer season, and a wish for physical exercise seems to be an important motivation for this choice. For ID9, the physical exercise rationale is less pronounced and mainly applies to his commute to his previous workplace, but it can also be seen in his considerations about buying an electric bike to replace some of his present car commuting. Physical exercise was an important rationale for ID11's commuting by bike to her previous workplace. After her job relocation, this rationale is countered by safety and caretaking concerns (see below), which, together with time-saving, makes her choose (e-)car driving instead. 
For some interviewees (ID5, ID6 and to some extent ID8), affective dislike of a certain travel mode influences the travel mode for commuting. For ID5, dislike of biking restricts her choice to be between car and transit (given that the commuting distance is beyond normally acceptable walking distance), where car comes up as the clearly fastest option and is thus preferred based on the time-saving rationale, which is her most important rationale. Distinct from ID5, ID6 has a dislike for car driving, expressed as a predilection for a car-less lifestyle. For him, the alternatives open for choice and subject to influence from his other transport rationales are transit, biking and walking, where the time-saving rationale excludes walking as a relevant alternative and the physical exercise alternative induces him to bike instead of traveling by transit during the summer season. For ID8, frustration associated with transit traveling (see below) may have turned into (or be amplified by) an active dislike of this mode, which then comes as an additional rationale for choosing modes other than transit. However, the 'active dislike' rationale seems more prominent for the husband of ID8 than for the interviewee herself.

Social contact/communication affects the travel mode choice of the interviewees ID5 and ID11, both female and working at workplaces at moderate distance from the city center of Oslo. These interviewees travel with their spouses to work, where the possibility to sort out and talk with the husband on the car trip (ID5) or communicate more generally adds to other rationales contributing to their choice of car driving as commuting mode. For ID11, caretaking is currently an additional rationale, since her husband has a broken leg and needs to be chauffeured to his workplace. A caretaking rationale also appears in the interview with ID2, who often drives her two teenagers to activities in connection with her journey home from work. The importance of this rationale for her choice of commuting mode is amplified by the fact that she is the only one with a driving license in the family (of four).

A safety rationale is encountered in the interviews with ID1 and ID11, working as a disincentive against biking. ID1, a peripheral-workplace employee, perceives parts of the bike route between home and work to be dangerous for bicyclists. For ID11, who works at Lysaker in the western part of Oslo, unsafe biking conditions along her present commuting route prevents her from pursuing her physical exercise rationale by commuting by bike, which she did to her previous workplace.

For ID2 and ID8, frustration aversion appears as an important rationale discouraging them from traveling by transit. ID2 switched to co-driving with a colleague in her previous commute, as she was discontent with people smoking at the metro station. For ID8, missing the connecting bus, incorrect timetables etc. were clear frustrating issues of transit commuting to an area not well served by public transportation. This rationale is closely related to a rationale of control and predictability encountered in the interview with ID3, who prefers not to travel by transit because she perceives this mode as unstable and the transit journey out of her control. For ID4, avoiding stress seems to play a role (along with other, more important rationales) for choosing not to drive (as well as being a negative aspect of cycling along inner-city streets). An obligation rationale exists for ID1, who is obliged by his employer to drive during the workday and often in connection with his journey to or from work. Finally, environmental concerns are explicit in the interview with ID12 and to some extent also ID11. Environmental concerns are also part of the reason for ID3's choice of cycling, although her main motivation is that commuting by bike is fastest. Environmental concerns possibly also play a role for ID6's predilection for a car-less lifestyle, although not explicitly stated in the interview, where he instead points at the money saved from not owning and driving a car.

\subsection{Interviewees' Narratives Exemplifying Travel Mode Rationales}

Below, narratives from the qualitative interviews are presented and linked to the main rationales described in the previous sub-section. The narratives are organized referring to three types of workplace locations; the central city-, the semi-central- and the suburban location.

\subsubsection{Commuting to Central City Workplace Locations}

Among the interviewees working in central city areas, reflections on commuting were very much centered on the high cost and low accessibility for car usage. Reflecting on both previous and current 
commuting practices, the interviewees described close to no car usage to central-city job locations. Hence, the travel expense and easiness of travel rationales worked in favor of other modes than car for this interviewee group. Common modes for this group were cycling or public transport. Walking, a mode typically related to short distances [67] seemed to be a less applied mode. This could be related to none of the inner-city workers having less than $5 \mathrm{~km}$ between dwelling and workplace location. It might also relate to that only one interviewee worked less than two kilometers from the city center, where our quantitative survey [7] showed walking to be more common than biking.

When explaining the avoidance of car commuting, its inconvenience and cost in dense urban areas was emphasized. It was simply considered to be too expensive and too much hassle to commute by car on a daily basis. An interviewee, both living and working in the central city (ID12), gave the following explanation for her choice of a transporter e-bike and not a car for the daily trips to work:

It makes no sense. [Driving by car] will take longer, or there is at least no time to save. There is parking at both ends [of the car commute], payment and there is the environment. (...) So why on Earth should I fill the inner city with my car?

The quote reflects both a practical and an environmental basis for commuting by bicycle, a transport mode she applies also during the winter. We see that while a time saving rationale is not central for her (saying that car and cycling requires more or less the same time usage), her mode choice clearly relates to rationales of travel expenses and easiness of travel. Reflecting on why she preferred the e-bike rather than public transport, the flexibility of the former in carrying out errands seemed important:

We think [transporter e-cycling] is very practical. It makes it easier for me to stop by a pharmacy or shop or making an errand. [I] think it's easier to bring things when I have a transporter e-cycle. I think pickup and delivery in kindergarten is easier with bike.

With low car usage and experiencing increasing cost and lack of parking availability in her neighborhood, this interviewee was planning to sell her car. Another interviewee, also he living and working centrally (ID4), related his low interest of buying a car to the increasing inconvenience of parking at the workplace location. Having three metro lines and no need for transfer between different lines, public transport was his most used mode. For him, flexibility to conduct errands to or from work was ensured by public transport providing high frequency and short travel time:

[I]f I want to stop somewhere in between [home and work], it's just to jump off. Let's say that I'm going to a meeting, or I'll buy something before I get to work, it's just to jump off somewhere. Then there will come another metro soon afterwards.

The interviews point to low car usage among those both living and working in the central city. However, the cost and inconvenience of commuting by car from the suburban to the central city seems to make this a less attractive option as well. Compared to the ones both living and working centrally, the issue of congestion on main inroads is emphasized. For one interviewee (ID10), having lived for long in the suburban area, car driving to her previous central city workplace was not an option due to congestion, together with expensive and little available parking. Another interviewee (ID9), driving between his suburban dwelling and workplace, drew a conclusion clearly relating to a rationale of limiting travel expenses when asked if he would still drive to a hypothetical workplace location in the central city:

Then I would have used the train, since parking barriers have become so extensive and difficult in Oslo. Not to mention that one has to drive through that toll ring.

\subsubsection{Commuting to Semi-Central Workplace Locations}

While congestion was not an issue for workers both living and working in the central city, coping strategies to avoid car congestion were more a theme for those working at semi-central locations. 
Furthermore, parking cost and lack of availability were less highlighted as disincentives for car usage at semi-central workplaces. For interviewees working in the semi-urban area, some free parking lots were provided by the employer. For ID11, the availability of free parking lots is part of her motivation for starting her workday at 7.30:

[W]e have a total of 11 lots, where four are reserved for electric cars until half past nine. None of them are payment lots. It is our 'first come-first served lots'.

The early morning departure of this interviewee is also motivated by a desire to avoid rush hour congestion. She also drives alternative routes with less traffic as a coping strategy to avoid congestion. This strategy was also used by ID5, describing how she and her co-driving husband formed a team to monitor day-by-day traffic and choose between a set of alternative routes. Hence, we see how use of car for work travel is related to a time saving rationale, but that coping strategies (such as early departure and flexible driving routes) are employed in order to actually make it a time-saving mode.

For another interviewee (ID8), inconvenience related to public transport made her switch to car when commuting to her previous semi-central workplace location:

It's a little embarrassing. I took the metro for maybe half a year. It takes so much time, I was about to go nuts. Walking to the metro-absolutely stuffed-switching metro-and then walk [the last distance to work]. It took over an hour. ( ... ) So, then I took the car. So, we bought two cars. It took 15 minutes by car.

The quote illustrates how her switch to car usage was based on a time saving rationale, an easiness of travel rationale and an affective dislike rationale (against public transport). When moving to the suburb, where she also got a job close to her dwelling, one of the two cars was sold and cycling to some extent replaced driving as transport mode to work.

\subsubsection{Commuting to Suburban Workplace Locations}

For the suburban job locations, the interviewees describe good conditions for car driving. Congestion seems moderate and when these situations occur, they are described as solvable. In particular, such congestion is found around sites of large urban development projects. Neither is parking an issue, it is free of charge and quite available at the suburban job locations. One respondent (ID10), though, described a previous lack of availability caused by park-and-ride drivers filling the workplace-lots when commuting from the nearby train station. This was solved when the employer provided the workers with a label, again making parking available. Explaining why she tended to drive between home and work, both located in the suburb, time-saving and flexibility was emphasized:

In part it has to do with time and in part it's related to my youngest daughter being a passenger. She co-rides part of the route.

Bringing children, together with errands, are also emphasized by another interviewee (ID2) living in a suburb in the southern part of the metropolitan area and working in a small town 11 kilometers further south:

I have two children aged 11 and 13 who are slightly dependent on some follow-up with leisure activities and so on. Often there is something related to them when I leave work, so that's why the car is often in use. Actually, I have really good bus access. I have a bus that stops 100 meters from my front door. It goes from there and stops outside [my workplace].

So, despite having available door-to-door transit, car commuting is the preferred mode in order to carry out various types of errands on the way. Hence, the choice of car instead of transit seems much related to a flexibility rationale. In contrast to the central city, car is the mode considered as providing flexibility at the outskirt. However, the interviewee also describes that her travel behavior could change in the future: 
I think that [in a few years], as my children grow older and no more depend so much on me. So, I have a little fantasy that then I will cycle and take the bus more often.

\section{Implications}

\subsection{Consequences of the Rationales for Relationships between Workplace Location and Commuting Distances}

Of the two main rationales influencing the interviewees' choices of workplace location, the rationale of choosing the best facility tends to make commuting distances shortest for those workplaces located close to large concentrations of potential employees, i.e., the centrally located workplaces. The rationale of limiting the friction of distance could lead to shorter commutes to suburban jobs, since the population is on average more decentralized than the jobs. However, for specialized jobs the likelihood of getting local employment may be low even for job seekers attaching high importance to the minimization of the friction of distance. Moreover, the limitation of friction of distance rationale induces inner-city residents to choose inner-city workplaces rather than suburban ones. Due to the high population density in the inner part of the metropolitan area, this contributes to reduce the commuting distances to centrally located workplaces.

Most of the interviewees attach strong importance to the 'best facility' rationale for choice of workplace location. Therefore, they do not necessarily choose the closest jobs, but rather they travel a bit further if they can then find a better job. This is also reflected in the questionnaire responses, where more than five times as many respondents mentioned the content of the job as one of the two main reasons for choosing their present workplace as its distance from the dwelling. The job applicant must be selected by the employer in competition with other applicants. This double requirement-that the job applicant must find the job attractive at the same time as the employer must find the job applicant attractive-implies that the number of both workers and jobs must be high in a local district to make local employment a likely outcome, particularly if the job requires specialized skills.

Our interviews showed an example (ID8) where one of the spouses of a household was able to find employment in the outer-suburban settlement where the other spouse was already working, which induced them to move from their previous, more centrally located dwellings to a dwelling close to her new job. This is, however, a rather atypical situation. More often, moving closer to one spouse's suburban workplace would increase the commuting distance of the other spouse. For example, this would have been the case if ID11 had moved closer to her new workplace, or if ID5, instead of finding a new job closer to home, had changed her place of residence to the peripheral town to which her previous workplace relocated a few years ago.

Commuting distances then depend more on the location of the workplace relative to large concentrations of dwellings than on the distance to the closest residential neighborhood, at least for workers with specialized qualifications. The population density is considerably higher in the central and inner city than in the outer parts of the urban region. The likelihood for a suburbanite to be employed at a local suburban workplace is, therefore, not very high. Workplaces close to the city center have a large number of potential employees within a short distance from the workplace and are, therefore, more likely to recruit workers locally.

For workers with less specialized qualifications, the possibility of finding employment closer to home is larger, and the incentives for employers to recruit employees from within a wide geographical area are fewer. Less specialized workers therefore have better opportunities to pursue the rationale of limiting the friction of distance. For workplaces with predominantly non-specialized jobs (such as primary and secondary schools, kindergartens, many kinds of non-specialized stores, warehouses etc.), the likelihood of recruiting local employees is higher, also in the suburbs, since applicants for such job will more often find the local job opportunities to be equally attractive as the more distant ones.

Table 1 summarizes the ways in which the different main rationales for workplace location choice tend to influence on the commuting distances to inner-city compared to suburban workplaces. 
Table 1. Rationales for workplace location choice and their implications for geographical differences in commuting distances.

\begin{tabular}{lcc}
\hline \multicolumn{1}{c}{ Rationales for Choice of Workplace Location } & $\begin{array}{c}\text { Encourages Commuting Distances } \\
\text { among Employees at Inner-City } \\
\text { Workplaces to Become: }\end{array}$ & $\begin{array}{c}\text { Encourages Commuting Distances } \\
\text { among Employees at Suburban } \\
\text { Workplaces to Become: }\end{array}$ \\
\hline $\begin{array}{l}\text { Choosing the 'best facility' (emphasized mostly by } \\
\text { interviewees without caretaking responsibilities) } \\
\text { Workers with highly specialized } \\
\text { qualifications } \\
\begin{array}{l}\text { Workers with less specialized } \\
\text { qualifications }\end{array}\end{array}$ & Somewhat longer \\
$\begin{array}{l}\text { Limiting the friction of distance (emphasized mostly } \\
\text { by interviewees with caretaking responsibilities) } \\
\text { Workers with highly specialized } \\
\text { qualifications } \\
\text { Workers with less specialized } \\
\text { qualifications }\end{array}$ & Slightly longer & Much longer \\
\hline
\end{tabular}

\subsection{Consequences of the Rationales for Relationships between Workplace Location and Commuting Modes}

The time-saving rationale for travel mode choice tends to encourage commuting by bike or transit to central workplaces and by car to peripheral workplaces. For employees at central workplaces, transit and bike are often faster than car, whereas the opposite is usually the case for employees at peripheral workplaces. This is also reflected in the actual travel modes of the interviewees. Only one of the six interviewees whose workplaces are within moderate distance from the city center and for whom time-saving is a main rationale for commuting mode choice commutes by car (ID5), and this is motivated largely with her possibility to drive together with her partner who has his workplace close to hers. Five of these six interviewees travel to their workplaces by transit or bike.

For the interviewees working at peripheral workplaces, the time-saving rationale normally encourages the use of car as commuting mode. Often, transit trips to peripheral workplaces require time-consuming shifts between different transit lines, and mismatch between train arrival times and the start of the workday represent additional time consumption. The exception from the car-inducing effect of the time-saving rationale among interviewees working at peripheral workplaces is if the commute is very short, but as mentioned above, for the interviewees with short commutes to peripheral workplace the time-saving rationale mainly refers to their travel mode choice before the relocation that resulted in a short commute.

The rationale of limiting travel expenses influences interviewees' commuting mode choices partly through its effect on car ownership and partly directly. Since car ownership and car travel are generally more expensive than using transit or non-motorized modes for intra-metropolitan commuting (especially in Oslo, where road tolls and parking costs make it expansive to drive to the inner city), employees at workplaces easily accessible by the latter modes usually have a greater opportunity to realize this rationale. The travel expenses rationale is therefore likely to add somewhat to the tendency of lower shares of car commuters at central than at peripheral workplaces.

Flexibility and convenience are other rationales making car an attractive travel mode to peripheral jobs, but parking conditions may make car an inconvenient mode to central workplaces. Instead, the fine-meshed transit network and frequent departures makes transit flexible and convenient for commuting to central workplaces. Low car convenience also increases the attractiveness of non-motorized modes. Among the interviewees whose workplaces are relatively centrally located, the four for whom these two rationales are important all commute by non-motorized modes or by transit.

The rationale of physical exercise encourages commuting by non-motorized modes and is likely to influence the actual mode choice in situations where other conditions also support the use of biking or walking as commuting modes (e.g., moderate commuting distance, inconvenient and slow access to the workplace by car, safe and pleasant biking and walking conditions). Such conditions are more likely to occur in central than in peripheral parts of the region, although unsafe biking conditions in the inner city of Oslo may work in the opposite direction. 
The impacts of the social contact/communication and caretaking rationales on commuting mode choice are unlikely to depend on whether the workplace is located in the outer or inner part of the metropolitan area. The same applies to the affective dislike rationale.

The impact of the safety rationale on commuting mode choice also does not appear clearly depending on whether the workplace is located in the outer or inner part of the metropolitan area. Local conditions, notably the provision of bike paths, are probably more important. Traffic conditions in the downtown area of Oslo may still be perceived as more unsafe (although traffic calming measures over recent decades have improved the safety situation for bicyclists considerably in the central part of the city).

Avoidance of stress and frustration discourages transit trips where transfer between lines is necessary and the frequency of departures is low. Both these situations are more typical for workplaces in the peripheral than in the central parts of the region. On the other hand, the rationale of avoiding stress and frustration discourages car trips in congested areas (typical around central workplaces).

The rationale of predictability and control works in similar ways.

Table 2 summarizes the ways in which the different rationales for travel mode choice contribute to producing the typical differences in commuting modes to inner-city compared to suburban workplaces.

Table 2. Travel mode choice rationales and their implications for geographical differences in commuting modes. Number of interviews in which each rationale was encountered is shown in parentheses.

\begin{tabular}{ccc}
\hline Rationales for Travel Mode Choice & $\begin{array}{c}\text { Travel Modes Encouraged for Employees } \\
\text { at Inner-City Workplaces }\end{array}$ & $\begin{array}{c}\text { Travel Modes Encouraged for Employees } \\
\text { at Suburban Workplaces }\end{array}$ \\
\hline Time-saving (12) & Transit and non-motorized & Car \\
Convenience (5) & Transit and non-motorized & Car \\
Limiting travel expenses (5) & Transit and non-motorized & Car \\
Flexibility (4) & Transit and non-motorized & Car \\
Croidance of stress and frustration (3) & Transit and non-motorized & Car \\
Predictability and control (1) & Transit and non-motorized & Non-motorized \\
Physical exercise (5) & Transit and non-motorized & Non-motorized \\
Environmental concerns (4) & Varying & Transit and non-motorized \\
Affective dislike (3) & Car & Varying \\
Car \\
Social contact/communication (2) & Motorized & Motorized \\
Caretaking (2) & Car & Car \\
Obligation (1) & Car & Car
\end{tabular}

Of the 13 rationales for commuting travel mode choice identified in the interviews, six (those shown in the upper part of Table 2) contribute more or less strongly to make car driving the most attractive travel mode when commuting to suburban workplaces and transit or non-motorized modes the most attractive ones when commuting to centrally located workplaces. Three of these six rationales (time-saving, convenience and flexibility) trigger quite strong mechanisms by which employees of suburban workplaces are induced to choose a car as their commuting mode whereas employees at central workplaces are induced to commute by transit or non-motorized modes. These three rationales, and particularly time-saving, are at the same time the rationales encountered most frequently among the interviewees. The rationale of limiting travel expenses works in the same direction. Two other rationales also contribute to the aforementioned typical differences between employees of suburban and central workplaces in commuting modes, although encountered in fewer interviews: avoidance of stress and frustration, and predictability and control.

None of the seven remaining rationales (shown in the lower part of Table 2) tends to counteract the differences between central and suburban workplaces in typical travel modes. The physical exercise rationale can stimulate non-motorized travel in inner-city as well as suburban situations, depending on the particular context (availability of bike paths/lines, sidewalks, pleasantness of the surroundings, etc.). In a similar way, the safety rationale can discourage non-motorized commuting (especially biking) to central as well as suburban workplaces, depending on the infrastructure and traffic situation along relevant routes. Finally, three rationales (social contact, caretaking and affective dislike) seem to affect the interviewees' travel modes in the same ways independently of the workplace location. 


\section{Concluding Remarks}

While a few studies have applied qualitative methods either to investigate ways in which workplace or residential relocation have influenced people's choices of commuting modes [68] or to explore individuals' location decision-making regarding job access [69], the present study is, to our knowledge, the first qualitative investigation of influences of workplace location on travel modes and distances. The interviewees' narratives and the transport rationales identified in the qualitative material have contributed to a deeper understanding of why employees working close to the main center of the metropolitan area commute by car less frequently and by transit more often than their counterparts at suburban workplaces do. The rationales of both suburban and central-city workers for choices among job opportunities also help in understanding why co-location of jobs and housing in suburban sub-centers does not lead to shorter overall commuting distances. Together, the qualitative interviews and the questionnaire survey data provide a more solid ground for conclusions about the travel behavioral impacts of intra-metropolitan differences in workplace location than in most previous studies on the topic.

The main rationales for workplace location and commuting mode choices found in this study show considerable similarity with rationales found in qualitative research on residential location and travel behavior [26-29,52]. Time-saving is the dominant rationale for travel mode choice among the interviewees. For employees at central workplaces, transit is often faster than car. For employees at peripheral workplaces, car is usually much faster than transit. Flexibility and convenience are other rationales making the car an attractive travel mode for peripheral jobs, while parking conditions may make car an inconvenient mode to central workplaces. Instead, the fine-meshed transit network and frequent departures makes transit flexible and convenient for commuting to central workplaces. Low car convenience in the inner city also makes non-motorized modes (particularly walking) more attractive. Avoidance of stress and frustration discourages transit trips where transfer between lines is necessary (typical for suburban workplaces) and discourages car trips in congested areas (typical around central workplaces). A rationale of predictability and control works in similar ways. The other rationales identified among the interviewees have more ambiguous implications for the relationship between workplace location and commuting mode choice, as they can in some cases increase but in other cases reduce the geographical differences in commuting behavior.

The rationales for workplace location choice show that people do not necessarily choose the closest jobs. They rather travel a bit farther if they can then find a better job. In addition, the job applicant must be selected by the employer in competition with other applicants. The likelihood for suburbanites to be employed at local suburban workplaces is, therefore, not very high, at least if the job requires specialized qualifications or there is more than one breadwinner in the household. Commuting distances thus depend more on the location of the workplace relative to large concentrations of dwellings than on its distance to the closest residential neighborhood. Workplaces close to the city center have a larger number of potential employees within a short distance from the workplace and are, therefore, more likely to recruit workers locally. For less specialized jobs, the incentives for workers to apply for non-local jobs and for employers to recruit non-local workers is lower, and for such jobs, a larger proportion of employees may live at moderate distances from suburban as well as centrally located workplaces.

The rationales for choices of workplace location and commuting modes encountered in our interviews can help understanding why several quantitative studies have found on average longer commuting distances (e.g., [8,11-13,15,17]) and higher proportions of car travel (e.g., [8-20]) to suburban than to centrally located jobs. By showing causal mechanisms underlying such aggregate patterns, our qualitative findings thus lend increased credibility to these earlier findings.

Author Contributions: P.N. conceptualized the work and designed the methodology. P.N. and A.T. conducted the interviews and carried out the interview interpretation. F.W. made the map showing the location of interviewees' workplaces. P.N. and A.T. wrote the original draft. P.N., A.T. and F.W. reviewed and edited the final draft.

Conflicts of Interest: The authors declare no conflict of interest. 


\section{Appendix A}

Table A1. Demographic, socioeconomic and spatial characteristics of the interviewees.

\begin{tabular}{|c|c|c|c|c|c|c|c|c|c|c|c|c|c|c|c|}
\hline $\begin{array}{l}\text { ID } \\
\text { Number }\end{array}$ & $\begin{array}{c}\text { Workplace } \\
\text { Location a; } \mathrm{km} \\
\text { from City } \\
\text { Center of Oslo } \\
\end{array}$ & $\begin{array}{c}\text { Work } \\
\text { Position }\end{array}$ & $\begin{array}{c}\text { Years of } \\
\text { Work at } \\
\text { Current } \\
\text { Work-Place } \\
\end{array}$ & Age & Gender & $\begin{array}{l}\text { Number } \\
\text { of Adult } \\
\text { Household } \\
\text { Members }\end{array}$ & $\begin{array}{c}\text { Number of } \\
\text { Children } \\
\text { below } \\
6 \text { Years } \\
\end{array}$ & $\begin{array}{l}\text { Number of } \\
\text { Children } \\
6-17 \text { Years }\end{array}$ & $\begin{array}{l}\text { Education } \\
\text { Level }\end{array}$ & $\begin{array}{l}\text { Personal } \\
\text { Income } \\
\text { (1000 NOK) }\end{array}$ & $\begin{array}{c}\text { Type of } \\
\text { Residential } \\
\text { Location }\end{array}$ & $\begin{array}{c}\text { Years of } \\
\text { Living in } \\
\text { Current } \\
\text { Neigh-Borhood }\end{array}$ & $\begin{array}{c}\text { Number } \\
\text { of Cars in } \\
\text { the } \\
\text { Household }\end{array}$ & $\begin{array}{c}\text { Main } \\
\text { Commuting } \\
\text { Mode }\end{array}$ & $\begin{array}{l}\text { Commuting } \\
\text { Distance ( (km } \\
\left.\text { one way }{ }^{b}\right)\end{array}$ \\
\hline 1 & $\begin{array}{l}\text { Ski } \\
(23)\end{array}$ & $\begin{array}{l}\text { Customer } \\
\text { contact }\end{array}$ & 24 & 56 & Male & 2 & 0 & 0 & $\begin{array}{c}\text { Skilled } \\
\text { worker/ } \\
\text { craftsman }\end{array}$ & 400 to 499 & $\begin{array}{l}\text { Outer suburb } \\
\text { (south) }\end{array}$ & 8 & 2 & Car & 6.7 \\
\hline 2 & $\begin{array}{l}\text { Ås } \\
(27)\end{array}$ & $\begin{array}{l}\text { Laboratory } \\
\text { engineer } \\
\text { Human }\end{array}$ & 4 & 42 & Female & 2 & 0 & 2 & Uni $\geq 4$ years & 600 to 699 & $\begin{array}{l}\text { Outer suburb } \\
\text { (south) }\end{array}$ & 8 & 1 & Car & 11.3 \\
\hline 3 & $\begin{array}{l}\text { Ås } \\
\text { (27) }\end{array}$ & $\begin{array}{l}\text { resources } \\
\text { (HR) } \\
\text { consultant } \\
\text { Information }\end{array}$ & 3.5 & 34 & Female & 2 & 2 & 0 & Uni $\geq 4$ years & 500 to 599 & $\begin{array}{l}\text { Outer suburb } \\
\text { (south) }\end{array}$ & 3 & 1 & Car & 1,2 \\
\hline 4 & $\begin{array}{l}\text { Oslo west } \\
\text { (4) }\end{array}$ & $\begin{array}{l}\text { technology } \\
\text { (IT) } \\
\text { developer }\end{array}$ & Less than 1 & 23 & Male & 4 & 0 & 0 & Uni $\geq 4$ years & $\begin{array}{c}\text { Below } \\
100\end{array}$ & $\begin{array}{l}\text { Downtown } \\
\text { Oslo }\end{array}$ & 2 & 0 & Transit & 4.0 \\
\hline 5 & $\begin{array}{l}\text { Oslo northeast } \\
\text { (5) }\end{array}$ & $\begin{array}{l}\text { Graphic } \\
\text { designer }\end{array}$ & Less than 3 & 33 & Female & 2 & 2 & 0 & $\begin{array}{l}\text { Skilled } \\
\text { worker/ } \\
\text { craftsw. }\end{array}$ & 500 to 599 & $\begin{array}{l}\text { Oslo suburb } \\
\text { (east) }\end{array}$ & Around 6 & 1 & Car & 5.3 \\
\hline 6 & $\begin{array}{l}\text { Oslo west } \\
\text { (4) }\end{array}$ & $\begin{array}{l}\text { IT game } \\
\text { designer }\end{array}$ & 5 (as student) & 29 & Male & 2 & 1 & 1 & Uni $\geq 4$ years & 400 to 499 & $\begin{array}{l}\text { Oslo suburb } \\
\text { (west) }\end{array}$ & 1 & 0 & Transit & 4.6 \\
\hline 7 & $\begin{array}{l}\text { Oslo west } \\
\text { (4) }\end{array}$ & $\begin{array}{l}\text { Software } \\
\text { manager }\end{array}$ & Less than 3 & 54 & Male & 3 & 0 & 0 & Uni $\geq 4$ years & 800 to 999 & $\begin{array}{l}\text { Inner suburb } \\
\text { (west) }\end{array}$ & 20 & 2 & Transit & 1.7 \\
\hline 8 & $\begin{array}{l}\text { As } \\
(27)\end{array}$ & Scientist & 4 & 34 & Female & 2 & 1 & 0 & Uni $\geq 4$ years & 400 to 499 & $\begin{array}{l}\text { Outer suburb } \\
\text { (south) }\end{array}$ & 2.5 & 1 & Walking & 0.4 \\
\hline 9 & $\begin{array}{l}\text { As } \\
(28)\end{array}$ & Teacher & 5 & 59 & Male & 3 & 0 & 0 & Uni $\leq 3$ years & 500 to 599 & $\begin{array}{l}\text { Outer suburb } \\
\text { (south) }\end{array}$ & 'all his life' & 3 & Car & 11.1 \\
\hline 10 & $\begin{array}{l}\text { As } \\
(28)\end{array}$ & Teacher & Nearly 3 & 46 & Female & 3 & 0 & 2 & Uni $\geq 4$ years & 600 to 699 & $\begin{array}{l}\text { Outer suburb } \\
\text { (south) }\end{array}$ & 'all her life' & 2 & Bike & 5.2 \\
\hline 11 & $\begin{array}{l}\text { Outer Oslo west } \\
\text { (6) }\end{array}$ & $\begin{array}{c}\text { Team } \\
\text { manager }\end{array}$ & 5 & 41 & Female & 2 & 0 & 2 & Uni $\geq 4$ years & 800 to 999 & $\begin{array}{l}\text { Inner suburb } \\
\text { (south) }\end{array}$ & $\begin{array}{l}\text { 14, plus } \\
\text { adjacent } \\
\text { dwelling } \\
\text { before }\end{array}$ & 2 & Car & 10.4 \\
\hline 12 & $\begin{array}{c}\text { Downtown Oslo } \\
(1.5)\end{array}$ & Consultant & $1 \frac{1}{2}$ & 31 & Female & 2 & 1 & 0 & Uni $\geq 4$ years & 400 to 499 & Inner Oslo & 11 & 1 & Bike & 2.5 \\
\hline 13 & $\begin{array}{c}\text { Downtown Oslo } \\
(1.5)\end{array}$ & $\begin{array}{l}\text { Associate } \\
\text { professor }\end{array}$ & Less than 3 & 39 & Female & 2 & 1 & 2 & Uni $\geq 4$ years & 600 to 699 & Inner Oslo & Not stated & 0 & Bike & 1.9 \\
\hline
\end{tabular}

Note: ${ }^{\text {a }}$ : See location names on the map in Figure $3{ }^{\mathrm{b}}$ : As the crow flies. 


\section{Appendix B. Interview Guide}

Topics to Be Addressed in Qualitative Interviews about Employees' Journeys to and from Work

The Norwegian University of Life Sciences, in cooperation with the Institute of Transport Economics, are conducting a study among employees at a number of workplaces in the Oslo region about journeys to and from work. The project is funded by the Norwegian Research Council. You are one of the survey respondents who volunteered to participate in a qualitative interview as part of this project.

The interview can take place at your workplace if this is possible, or in your home. Other locations may also be chosen if they are more convenient. One or two researchers will participate in the interview. Each interview is expected to last for $30-45 \mathrm{~min}$. The sequence of topics will be adapted to the situation of each specific interview and may not necessarily follow the order displayed in this guide. The interviews will be audio-recorded and transcribed in their entirety (yet without including coughs, stuttering, repeated words, etc.). The transcript will be treated confidentially. In addition, the interview material will be anonymized at the end of the project period.

The following topics will be addressed in the interview:

- General thoughts on the importance to you of this job and location of the workplace;

- Reasons why you chose to work/ended up working at precisely this workplace;

- Thoughts about your choice of travel mode(s) for your journeys to/from work;

- Any routine activities in connection with your journey to and from work-daily necessities shopping, bringing/picking up children, etc.;

- Changes in your travel (traveling distance, modes of travel, etc.) to and from the workplace, compared to your previous workplace;

- Any change in residential location during recent years, or plans for future residential relocation;

- Frequency of attendance at the workplace, and any changes due to job or residential relocation;

- Car ownership, and any changes of this;

- Rounding off. 


\section{Appendix C}

Table A2. An excerpt of the 9-page synthesizing interpretation of the question group: rationales for travel mode choices.

\begin{tabular}{|c|c|c|c|}
\hline $\begin{array}{l}\text { Excerpt ( } 157 \text { of } 2546 \text { Words) of Final Synthesis for the Question Group } \\
\text { "Rationales for Travel Mode Choices" }\end{array}$ & $\begin{array}{l}\text { Interviewees (Only One } \\
\text { Shown Here) }\end{array}$ & Questions & Interpretation \\
\hline $\begin{array}{l}\text { For the interviewees working at peripheral workplaces, the time-saving rationale } \\
\text { normally encourages the use of a car as commuting mode. Often, transit trips to } \\
\text { peripheral workplaces require time-consuming shifts between different transit } \\
\text { lines, and mismatch between train arrival times and the start of the workday } \\
\text { represent additional time consumption. The exception from the car-inducing } \\
\text { effect of the time-saving rationale among interviewees working at peripheral } \\
\text { workplaces is if the commute is very short, but as mentioned above, for the } \\
\text { interviewees with short commutes to peripheral workplace the time-saving } \\
\text { rationale mainly refers to their travel mode choice before the relocation that } \\
\text { resulted in a short commute. } \\
\text { Limiting travel expenses appears as an important rationale for some interviewees, }\end{array}$ & \multirow[t]{2}{*}{$\begin{array}{l}\text { ID } 5 \\
\text { F } 33 \\
\text { Workplace: Bjørklund } \\
\text { Location: Vollebekk }\end{array}$} & $\begin{array}{l}\text { 8. What underlying rationales for travel } \\
\text { mode choice can be inferred from the } \\
\text { interviewee's answers to the questions } \\
\text { about reasons for travel mode choice up } \\
\text { to present and previous workplace(s)? }\end{array}$ & $\begin{array}{l}\text { Time-saving is the most important rationale. This is } \\
\text { also evident in their efforts in finding ways to avoid } \\
\text { congestion, monitoring traffic and selecting routes in } \\
\text { accordance with congestion levels. In addition, } \\
\text { dislike for a potential alternative mode (biking) } \\
\text { restricts her choice to between car and transit, where } \\
\text { car comes up as the clearly fastest option. Limiting } \\
\text { travel expenses is also important, since she would } \\
\text { rather travel by transit if she could not be a car } \\
\text { passenger with her husband than purchase another } \\
\text { car enabling here to drive on her own to her job. } \\
\text { Social contact and communication also plays a role, } \\
\text { understood as the possibility to sort out and talk with } \\
\text { her husband on the car trip home from work. }\end{array}$ \\
\hline $\begin{array}{l}\text { ID5, who regularly travels to her workplace as a car passenger with her husband } \\
\text { states that she would rather travel by transit than purchase another car enabling } \\
\text { here to drive on her own to her job if she could not drive with her husband. }\end{array}$ & & $\begin{array}{l}\text { 11. Can any rationales for activity } \\
\text { location and travel mode choice be } \\
\text { inferred from the reasons given by the } \\
\text { interviewees for their change in } \\
\text { residential location? }\end{array}$ & $\begin{array}{l}\text { Not really, since it seems that the choice of where to } \\
\text { live was decided mainly by her partner-and for } \\
\text { him, place attachment seemed to be important since } \\
\text { Ellingsrud was the place he came from. It is not } \\
\text { clear from the interview whether her current } \\
\text { partner is the same as the one she lived with at Carl } \\
\text { Berners plass, where she says they consciously } \\
\text { chose not to have a car. }\end{array}$ \\
\hline
\end{tabular}




\section{References}

1. Hägerstrand, T. Urbaniseringen af Sverige_En Geografisk Samhällsanalys; Appendix 4 of SOU 1970:14; The Urbanization of SWEDEN-A Geographical Analysis of Society: Stockholm, Sweden, 1970.

2. Ewing, R.; Cervero, R. Travel and the built environment. J. Am. Plan. Asso. 2010, 76, 1-30. [CrossRef]

3. Stevens, M.R. Does compact development make people drive less? J. Am. Plan. Assoc. 2017, 83, 7-18. [CrossRef]

4. Røe, P.G. Storbymenneskets Hverdagsreiser. Sammenhenger mellom Bosted, Livsstil og Hverdagsreisepraksis i et Senmoderne Perspektiv. Ph.D. Thesis, Norwegian University of Technology and Science, Trondheim, Norway, 2001.

5. Clifton, K.J.; Handy, S.L. Qualitative methods in travel behaviour research. In Transport Survey Quality and Innovation; Stopher, P., Jones, P., Eds.; Pergamon: Oxford, UK, 2003; pp. 283-302.

6. Handy, S. Thoughts on the Meaning of Mark Stevens's Meta-Analysis. J. Am. Plan. Assoc. 2017, 83, $26-28$. [CrossRef]

7. Wolday, F.; Næss, P.; Tønnesen, A. Workplace location, polycentricism and car commuting. Paper under review.

8. Cervero, R.; Landis, J. Suburbanization of jobs and the journey to work: A submarket analysis of commuting in the San Francisco Bay area. J. Adv. Transp. 1992, 26, 275-297. [CrossRef]

9. Dasgupta, M. Urban travel demand and policy impacts. In Proceedings of the Course "The Urban Environment and Transport Policy" at the Norwegian Institute of Technology, Trondheim, Norway, 10-12 January 1994.

10. Schwanen, T.; Dieleman, F.M.; Dijst, M. Travel behaviour in Dutch monocentric and policentric urban systems. J. Transp. Geogr. 2001, 9, 173-186. [CrossRef]

11. Yang, J. Commuting impacts of spatial decentralization: A comparison of Atlanta and Boston. J. Reg. Anal. Policy 2005, 35, 69-78.

12. Aguiléra, A.; Wenglenski, S.; Proulhac, L. Employment suburbanisation, reverse commuting and travel behavior by residents of the central city in the Paris metropolitan area. Transp. Res. 2009, 43, 685-691.

13. Vale, D.; Pereira, M.; Viana, C.M. Different destination, different commuting pattern? Analyzing the influence of the campus location on commuting. J. Transp. Land Use 2018, 11, 1-18. [CrossRef]

14. Martamo, R. Työssäkäyntietäisyydet Suomessa (Distance between Workplace and Residence in Finland); Miljöministeriet, Markanvändingsavdelningen: Helsinki, Finland, 1995.

15. Hartoft-Nielsen, P. Arbejdspladslokalisering og Transportadfærd; Forskningscenteret for Skov og Landskab: Hørsholm, Denmark, 2001.

16. Næss, P. The impacts of job and household decentralization on commuting distances and travel modes: Experiences from the Copenhagen region and other urban areas. Informationen zur Raumentwicklung 2007, 2/3, 149-168.

17. Strømmen, K. Rett Virksomhet på rett sted-Om Virksomheters Transportskapende Egenskaper. Ph.D. Thesis, Norwegian University of Technology and Science, Trondheim, Norway, 2001.

18. Næss, P.; Strand, A.; Wolday, F.; Stefansdottir, H. Residential location, commuting and non-work travel in two urban areas of different size and with different center structures. Prog. Plan. 2019, 1-36. [CrossRef]

19. Engebretsen, Ø.; Næss, P.; Strand, A. Residential location, workplace location and car driving in four Norwegian cities. Eur. Plan. Stud. 2018, 26, 2036-2057. [CrossRef]

20. Næss, P.; Sandberg, S.L. Workplace location, modal split and energy use for commuting trips. Urban Stud. 1996, 33, 557-580. [CrossRef]

21. Crane, R.; Chatman, D. As jobs sprawl, whither the commute? Access 2003, 23, 14-19.

22. Guth, D.; Holz-Rau, C.; Maciolek, M. Employment suburbanisation and commuter traffic in German city regions. In Proceedings of the 9th Swiss Transport Research Conference, Ascona, Switzerland, 9-11 September 2009.

23. Tillberg, K. Barnfamiljers Dagliga Fritidsresor i Bilsamhället-Ett Tidspussel med Geografiska og Könsmässiga Variationer; Geografiska Regionstudier nr. 43; Uppsala University: Uppsala, Sweden, 2001.

24. Nielsen, T.A.S. Boliglokalisering og Transport i Aalborg. Ph.D. Thesis, Aalborg University, Aalborg, Denmark, 2002.

25. Næss, P.; Jensen, O.B. Urban Structure Matters, Even in a Small Town. J. Environ. Plan. Manag. 2004, 47, 35-56. [CrossRef] 
26. Næss, P.; Jensen, O.B. Bilringene og Cykelnavet: Boliglokalisering, Bilafhængighed og Transportadfærd $i$ Hovedstadsområdet; Aalborg University Press: Aalborg, Denmark, 2005.

27. Næss, P. Residential Location Affects Travel Behavior-But How and Why? The case of Copenhagen Metropolitan Area. Prog. Plan. 2005, 63, 167-257. [CrossRef]

28. Næss, P. Residential location, transport rationales and daily-life travel behavior: The case of Hangzhou Metropolitan Area, China. Prog. Plan. 2013, 79, 1-50. [CrossRef]

29. Næss, P. Residential location and travel behavior. In Mobility Patterns and Urban Structure; Pinho, P., Silva, C., Eds.; Ashgate: Farnham, UK, 2015; Chapter 8; pp. 151-186.

30. Scheiner, J. Daily mobility in Berlin: on 'Inner Unity' and the explanation of travel behaviour. Eur. J. Transp. Infrastruct. Res. 2005, 5, 159-186.

31. Stanbridge, K.; Lyons, G. Travel behaviour considerations during the process of residential relocation. In Proceedings of the 11th International Conference on Travel Behaviour Research, Kyoto, Japan, 16-20 August 2006.

32. Schwanen, T. On 'arriving on time', but what is 'on time'? Geoforum 2006, 37, 882-894. [CrossRef]

33. Schwanen, T. Managing uncertain arrival times through sociomaterial associations. Environ. Plan. B Plan. Des. 2008, 35, 997-1011. [CrossRef]

34. Schwanen, T. Struggling with Time: Investigating Coupling Constraints. Transp. Rev. 2008, 28, 337-356. [CrossRef]

35. Guell, C.; Panter, J.; Jones, N.R.; Ogilvie, D. Towards a differentiated understanding of active travel behaviour: Using social theory to explore everyday commuting. Soc. Sci. Med. 2008, 75, 233-239. [CrossRef] [PubMed]

36. Venter, C.; Shukrani, K.; Minora, N.; Du Toit, J. A role for GPS data in qualitative research: Exploring links between walking behavior, the built environment, and crime perception in South Africa. In Mobile Technologies for Activity-Travel Data Collection and Analysis; Soora, R., Ed.; IGI Global: Hershey, PA, USA, 2014.

37. Ferrer, S.; Ruiza, T.; Mars, L. A qualitative study on the role of the built environment for short walking trips. Transp. Res. Part F Traffic Psychol. Behav. 2015, 33, 141-160. [CrossRef]

38. Hess, F.; Salze, P.; Weber, C.; Feuillet, T.; Charreire, H.; Menai, M.; Perchoux, C.; Nazare, J.A.; Simon, C.; Oppert, J.M.; et al. Active Mobility and Environment: A Pilot Qualitative Study for the Design of a New Questionnaire. PLoS ONE 2017, 12, e0168986. [CrossRef] [PubMed]

39. Stefansdottir, H. The role of urban atmosphere for non-work activity locations. J. Urban Des. 2018, 23, 319-335. [CrossRef]

40. Næs, P. Validating explanatory qualitative research: Enhancing the interpretation of interviews in urban planning and transportation research. Appl. Mobil. 2018. [CrossRef]

41. Sartre, J.P. Being and Nothingness; Philosophical Library: New York, NY, USA, 1948.

42. Gibson, J. The theory of affordances. In Perceiving, Acting, and Knowing. Toward an Ecological Psychology; Shaw, R., Bransford, J., Eds.; Lawrence Erlbaum: Hillsdale, NJ, USA, 1977; pp. 67-82.

43. Østerberg, D. Arkitektur og sosiologi i Oslo: En Sosiomateriell Fortolkning [Architecture and Sociology in Oslo: A Socio-Material Interpretation]; Pax: Oslo, Norway, 1998.

44. Næss, P. Built Environment, Causality and Travel. Transp. Rev. 2015, 35, 275-291. [CrossRef]

45. Næss, P. Built Environment, Causality and Urban Planning. Plan. Theory Pract. 2016, 17, 52-71. [CrossRef]

46. Bhaskar, R. Enlightened Common Sense. The philosophy of Critical Realism; Routledge: London, UK; New York, NY, USA, 2016.

47. Archer, M.S. Being Human. The Problem of Agency; Cambridge University Press: Cambridge, UK, 2000.

48. Danermark, B.; Ekström, M.; Jacobsen, L.; Karlsson, J.C. Explaining Society. Critical Realism in the social Sciences; Routledge: London, UK; New York, NY, USA, 2001.

49. Lloyd, P.E.; Dicken, P. Location in Space-A Theoretical Approach to Economic Geography; Harper \& Row: London, UK, 1977.

50. Alonso, W. Location and Land Use; Harvard University Press: Cambridge, MA, USA, 1964.

51. Allpass, J.; Ågergard, E.; Harvest, J.; Olsen, P.A.; Søholt, S. Urban centres and changes in the centre structure. In Proceedings of the International Study Week, Amsterdam, The Netherlands, 11-17 September 1966; Brill: Leiden, The Nehterlands, 1967; pp. 103-117.

52. Næss, P.; Peters, S.; Stefansdottir, H.; Strand, A. Causality, not just correlation: Residential location, transport rationales and travel behavior across metropolitan contexts. J. Transp. Geogr. 2018, 69, 181-195. [CrossRef]

53. Habermas, J. The Theory of Communicative Action. Polity Press: Oxford, UK, 1991; Volumes 1-2. 
54. Tuan, Y. Space and Place. The Perspective of Experience; The University of Minnesota Press: Minneapolis, MI, USA, 1977.

55. Statistics Norway. Population statistics (Folkemengde og befolkningsendringer). 2018. Available online: http:/ / www.ssb.no (accessed on 22 August 2018).

56. Statistics Norway. Population and Land Area in Urban Settlements (Befolkning og areal i tettsteder). 2018. Available online: http:/ / www.ssb.no (accessed on 19 December 2018).

57. Kenworthy, J.R.; Inbakaran, C. Differences in transport and land use in thirteen comparable Australian, American, Canadian and European cities between 1995/6 to 2005/6 and their implications for more sustainable transport. In Proceedings of the 34th Australasian Transport Research Forum (ATRF), Adelaide, Australia, 28-30 September 2011.

58. Hjorthol, R.; Engebretsen, Ø.; Uteng, T.P. Den Nasjonale Reisevaneundersøkelsen 2013/14-Nøkkelrapport; Institute of Transport Economics: Oslo, Norway, 2014.

59. Cooperation Report. Impact Assessment-Transport; (KVU Oslo-Navet); Ruter, Statens vegvesen, Jernbanedirektoratet: Oslo, Norway, 2015.

60. Gerring, J. What is a case study and what is it good for? Am. Polit. Sci. Rev. 2004, 98, 341-354. [CrossRef]

61. Glaser, B.G.; Strauss, A.L. The Discovery of Grounded Theory. Strategies for Qualitative Research; Aldine Transaction: New Brunswick, NJ, USA, 1967.

62. Minichiello, V.; Aroni, R.; Timewell, E.; Alexander, L. In-Depth Interviewing: Researching People; Longman Cheshire Pty Limited: Hong Kong, China, 1990.

63. Yin, K.R. Case Study Research. Design and Methods, 2nd ed.; Sage Publications: Thousand Oaks, CA, USA, 1994.

64. Cresswell, J. Research Design: Qualitative, Quantitative, and Mixed Methods Approaches; Sage: Los Angeles, CA, USA, 2003.

65. Maxwell, J.A. Using qualitative methods for causal explanation. Field Methods 2004, 16, 243-264. [CrossRef]

66. Kvale, S. InterViews: An Introduction to Qualitative Research Interviewing; Sage: Thousand Oaks, CA, USA, 1996.

67. Scheiner, J. Interrelations between travel mode choice and trip distance: trends in Germany 1976-2002. J. Transp. Geogr. 2010, 18, 75-84. [CrossRef]

68. Jones, C.H.D.; Ogilvie, D. Motivations for active commuting: a qualitative investigation of the period of home or work relocation. Int. J. Behav. Nutr. Phys. Act. 2012, 9, 109. [CrossRef] [PubMed]

69. Boschmann, E.E. Job access, location decision, and the working poor: A qualitative study in the Columbus, Ohio metropolitan area. Geoforum 2011, 42, 671-682. [CrossRef] 